\title{
PENGARUH SUPLEMENTASI MINYAK IKAN DAN L-KARNITIN DALAM PAKAN JAGUNG KUNING TERFERMENTASI TERHADAP KECERNAAN PAKAN DAN PERFORMA PUYUH (Coturnix coturnix japonica)
}

\section{THE EFFECTS OF FISH OIL AND L-CARNITINE SUPPLEMENTATION IN THE DIET CONTAINING FERMENTED YELLOW CORN ON FEED DIGESTIBILITY AND PERFORMANCE OF JAPANESE QUAIL (Coturnix coturnix japonica)}

\author{
Sinelsa Wulandari Sany*, Setiana Rohmi Heswantari, Sudibya, Sutrisno Hadi Purnomo, \\ dan Aqni Hanifa \\ Jurusan Peternakan, Fakultas Pertanian, Universitas Sebelas Maret, Surakarta, 57126
}

Submitted: 15 July 2014, Accepted: 2 January 2015

\section{INTISARI}

\begin{abstract}
Penelitian ini bertujuan untuk mengetahui pengaruh suplementasi minyak ikan dan L-karnitin dalam pakan jagung kuning terfermentasi terhadap kecernaan pakan dan performa produksi puyuh (Coturnix coturnix japonica). Penelitian ini menggunakan 160 ekor puyuh yang berumur 70 hari yang dibagi ke dalam lima macam perlakuan dan empat ulangan. Setiap ulangan terdiri dari delapan ekor

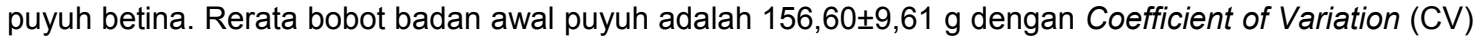
$6,14 \%$. Pengukuran kecernaan in vivo dilakukan pada minggu terakhir penelitian dengan metode total koleksi. Puyuh diambil secara acak sebanyak dua ekor dari setiap satuan percobaan kemudian ditempatkan dalam kandang individu, sehingga secara keseluruhan digunakan 40 ekor puyuh berumur 133 hari untuk pengukuran kecernaan. Desain penelitian yang digunakan adalah Rancangan Acak Lengkap dengan lima perlakuan yaitu $\mathrm{P}_{0}=$ pakan basal (bekatul, konsentrat, jagung kuning), $\mathrm{P}_{1}=$ Bekatul, konsentrat dan jagung kuning terfermentasi, $\mathrm{P}_{2}=$ pakan $\mathrm{P}_{1}+L$-karnitin $10 \mathrm{ppm}, \mathrm{P}_{3}=$ pakan $\mathrm{P}_{2}+$ minyak ikan tuna $4 \%$, dan $\mathrm{P}_{4}=$ pakan $\mathrm{P}_{2}+$ minyak ikan lemuru $4 \%$. Peubah yang diamati yaitu kecernaan bahan kering (KcBK), kecernaan bahan organik (KcBO), kecernaan lemak kasar (KcLK), konsumsi pakan, Hen Day Production (HDP), berat telur, dan konversi pakan. Hasil analisis variansi menunjukkan bahwa substitusi jagung kuning dengan jagung kuning terfermentasi meningkatkan KcBK, KcBO, KcLK, konsumsi pakan dan berat telur. Suplementasi L-karnitin ke dalam pakan jagung kuning terfermentasi mampu meningkatkan HDP, sedangkan suplementasi minyak ikan mampu menurunkan nilai konversi pakan. Kesimpulan yang dapat diambil dari penelitian ini adalah bahwa suplementasi $L$-karnitin $10 \mathrm{ppm}$ ke dalam pakan mampu memperbaiki HDP. Substitusi jagung kuning dengan jagung kuning fermentasi dapat meningkatkan KcBK, KcBO, KcLK, dan berat telur. Suplementasi minyak ikan tuna $4 \%$ ke dalam pakan mampu meningkatkan berat telur. Kemudian suplementasi minyak ikan tuna dan minyak ikan lemuru pada pakan jagung kuning tanpa fermentasi mampu memperbaiki nilai konversi pakan puyuh fase produksi.
\end{abstract}

(Kata kunci: Jagung kuning terfermentasi, L-karnitin, Minyak ikan, Performa, Puyuh)

\section{ABSTRACT}

The research was aimed to determine the effect of fish oil and L-carnitine supplementation in fermented yellow corn diets on the performance of quail (Coturnix coturnix japonica). The experiment was used 160 quails aged 70 days that were divided into five treatments and four replications. Each replication consisted of eight female quails. The mean initial body weight was $156.60 \pm 9.61 \mathrm{~g}$ with Coefficient of Variance (CV) of $6.14 \%$. The in-vivo digestibility study was carried out on the last week using total collection method. Two quails were chosen randomly from each cage and placed into individual raised cages. Overall this experiment used 40 quails for nutrient digestibility study. The research was carried out using a completely randomized design. The experimental diets were $P_{0}=$ basal diet (ricebran, concentrates, yellow corn), $P 1=$ ricebran, concentrate and fermented yellow corn, $P_{2}=P_{1}$ feed $+10 \mathrm{ppm}$ of L-carnitine, $P_{3}=P 2$ feed $+4 \%$ of tuna fish oil, and $P_{4}=P_{2}$ feed $+4 \%$ of lemuru fish oil. The observed variables were dry matter digestibility, organic matter digestibility, extract ether digestibility, feed consumption, HDP, egg weight and feed conversion ratio. The results of variance analysis showed that

\footnotetext{
* Korespondensi (corresponding author):

Telp. +62 85712720571

E-mail: sinelsasany@ymail.com
} 
substitution of yellow corn with fermented yellow corn increased dry matter digestibility, organic matter digestibility, extract ether digestibility, feed intake and egg weight, whereas the addition of L-carnitine in the diet of fermented yellow corn increased the value of the HDP and improved feed conversion. Substitution of yellow corn with fermented yellow corn in the feed increased dry matter digestibility, organic matter digestibility, extract ether digestibility, egg weight, whereas the addition of L-carnitine 10 ppm in the feed of fermented yellow corn improved the HDP. Suplementation of tuna fish oil $4 \%$ in the diets increased egg weight. Suplementation of tuna fish oil and lemuru fish oil in the yellow corn supplemented diets improved feed conversion of quail at production phase.

(Key words: Fermented yellow corn, Fish oil, L-carnitine, Growth performance, Japanese quail)

\section{Pendahuluan}

Puyuh merupakan jenis ternak yang memiliki prospek usaha yang cukup bagus. Sumbangan puyuh dalam menyediakan sumber protein hewani bagi masyarakat Indonesia yaitu mencapai lebih dari $10 \%$ (Prahasta dan Masturi, 2009). Produktivitas puyuh cukup tinggi yaitu 250-300 butir/ekor/tahun (Narinc et al., 2013). Produktivitas puyuh masih bisa ditingkatkan lagi dengan tujuan tercukupinya ketersediaan protein hewani bagi masyarakat Indonesia.

Feed additive yang dapat digunakan dalam upaya peningkatan produktivitas puyuh salah satunya yaitu L-karnitin. Lkarnitin mempunyai potensi yang positif untuk meningkatkan pertumbuhan dan katabolisme lemak (Mohseni et al., 2008) sehingga sangat dibutuhkan dalam pakan yang mengandung lemak. Beberapa fungsi lain dari L-karnitin yaitu sebagai fasilitator metabolisme yang diperlukan untuk mengoksidasi asam lemak rantai panjang dalam mitokondria, lalu menghasilkan energi metabolik (Flanagan et al., 2010; Zhang et al., 2014) sehingga energi untuk hidup puyuh lebih cepat dihasilkan. Suplementasi Lkarnitin dalam pakan diharapkan dapat meningkatkan kecernaan nutrien dan memperbaiki nilai konversi (James et al., 2013).

Selain penambahan feed additive, upaya peningkatan produktivitas juga dapat dilakukan dengan penggunaan teknologi pengolahan bahan pakan, misalnya fermentasi. L-karnitin mampu mengontrol berat telur puyuh fase produksi pada suplementasi minyak ikan tuna $4 \%$ dalam pakan. Hal ini disebabkan karena minyak ikan tuna dan L-karnitin bersinergi membantu meningkatkan metabolisme tubuh, walaupun konsumsinya berkurang tetapi tidak memengaruhi produksi telur (Kusuma, 2013).
Minyak bisa dijadikan sebagai sumber energi pada pakan unggas (Bess et al., 2011), begitu pula dengan minyak ikan. Selain itu, minyak juga bermanfaat membantu absorpsi vitamin-vitamin yang larut dalam lemak serta mengurangi sifat berdebu dalam pakan (Franz et al., 2010). Suplementasi minyak ikan dalam pakan merupakan salah satu metode untuk memenuhi kebutuhan asam lemak tak jenuh pada pakan unggas karena mengandung asam lemak omega-3 yang tinggi (asam lemak tidak jenuh/PUFA) (Shin et al., 2011). Suplementasi minyak ikan tuna $4 \%$ dalam pakan mampu memperbaiki nilai konversi pakan puyuh fase produksi (Kusuma, 2013). Jagung merupakan bahan pakan yang penting dalam menyediakan energi, protein, lemak, dan serat bagi ternak yang biasanya digunakan dalam bahan pakan. Sementara itu, fermentasi bertujuan untuk meningkatkan nilai kecernaan bahan pakan, sehingga nilai penyerapan nutrien pakan lebih optimal, yang pada akhirnya produktivitas akan meningkat. Saccaromyces cereviceae yang digunakan dalam fermentasi dilaporkan dapat meningkatkan kecernaan pakan berserat tinggi (Zerby et al., 2010).

Proses fermentasi dengan ragi tape dapat menyebabkan perubahan terhadap komposisi kimia bahan, seperti kandungan asam amino, lemak, karbohidrat, vitamin dan mineral akibat aktivitas perkembangbiakan mikroorganisme (Zerby et al., 2010). Fermentasi dengan Aspergillus niger pada itik jantan umur 5-10 minggu menurunkan kandungan serat kasar sebesar 2,39\%, meningkatkan protein kasar sebesar $4,20 \%$, meningkatkan konsumsi pakan sebanyak 49 gram dan menurunkan konversi pakan sebesar 0,47 . Penggunaan jagung kuning terfermentasi, minyak ikan tuna, minyak ikan lemuru dan L-karnitin pada penelitian ini diharapkan mampu memberikan efek gabungan bahan pakan yang positif sehingga mampu memperbaiki kecernaan, 
konsumsi pakan, HDP, bobot telur, dan konversi pakan puyuh petelur.

\section{Materi dan Metode}

\section{Materi}

Penelitian ini dilaksanakan selama 2 bulan yaitu mulai bulan September sampai November 2013 di Desa Gledeg, Kecamatan Karanganom, Kabupaten Klaten. Analisis proksimat Bahan Kering, Bahan Organik dan Lemak Kasar dilakukan di Laboratorium Pusat MIPA Universitas Sebelas Maret, Surakarta. Penelitian ini menggunakan burung puyuh betina umur 70 hari sebanyak 160 ekor dengan rerata bobot badan awal adalah 156,60 $\pm 9,61 \mathrm{~g}$ dan Coefficient Variance (CV) 6,14\%. Susunan pakan perlakuan puyuh beserta kandungan nutriennya disajikan pada Tabel 1 .

\section{Metode}

Rancangan percobaaan yang digunakan yaitu Rancangan Acak Lengkap. Penelitian ini menggunakan 5 perlakuan dan masing-masing perlakuan diulang sebanyak 4 kali. Ulangan terdiri dari 8 ekor puyuh betina. Adapun perlakuannya adalah sebagai berikut: $\quad \mathrm{P}_{0}=$ pakan basal (bekatul, konsentrat, dan jagung kuning), $\mathrm{P}_{1}=\mathrm{P}_{0}+$ $100 \%$ jagung kuning terfermentasi untuk substitusi jagung kuning dalam pakan, $\mathrm{P}_{2}=$ $\mathrm{P}_{1}+$ L-karnitin 10 ppm (10 ppm setara dengan $0,001 \%), \mathrm{P}_{3}=\mathrm{P}_{2}+$ minyak ikan tuna $4 \%$ dalam pakan, dan $\mathrm{P}_{4}=\mathrm{P}_{2}+$ minyak ikan lemuru $4 \%$ dalam pakan.

\section{Persiapan penelitian}

Persiapan kandang dilakukan sebelum pemeliharaan dimulai, terlebih dahulu kandang dibersihkan kemudian dilakukan proses desinfeksi menggunakan desinfektan. Pengapuran lantai dilakukan setelah kandang selesai didesinfeksi. Kegiatan lain yang dilakukan yaitu pencucian tempat pakan dan minum kemudian merendamnya dalam larutan antiseptik lalu dijemur di bawah sinar matahari hingga kering. Puyuh betina umur 70 hari sebanyak 160 ekor terlebih dahulu ditimbang dengan menggunakan timbangan digital untuk mengetahui bobot badan awal pada saat penelitian. Puyuh betina sebanyak 160 ekor tersebut dibagi ke dalam lima kelompok perlakuan yang diulang sebanyak empat kali dan setiap ulangan terdiri dari delapan ekor puyuh betina.

Persiapan pakan diawali dengan persiapan bahan. Proses fermentasi jagung terlebih dulu dilakukan untuk mendapatkan bahan jagung kuning fermentasi. Bahan jagung kuning yang digunakan yaitu jagung kuning yang sudah digiling. Cara fermentasi diawali dengan pengukusan jagung kuning hingga matang, kemudian ditiriskan di atas plastik hingga dingin, setelah dingin, jagung diberi ragi tape dengan perbandingan 30:2, tiap $30 \mathrm{~kg}$ jagung diberi $30 \mathrm{~g}$ ragi tape. Jagung dibagi ke dalam empat bagian, agar pencampuran ragi tape dapat homogen dan merata. Jagung kuning yang sudah diberi ragi tape segera ditutup dengan plastik dan dibiarkan selama tiga hari, setelah tiga hari proses fermentasi, jagung kuning fermentasi ditiriskan kembali dan dijemur di bawah sinar matahari hingga kering.

Pencampuran bahan untuk pakan dilakukan setiap 3 hari sekali dengan cara mencampur bahan-bahan yang terkecil kemudian bahan-bahan yang besar agar pencampurannya bisa merata atau homogen. Pencampuran minyak ikan lebih sesuai dengan bekatul karena sifat bekatul yang bisa menyerap minyak, sedangkan $L$ karnitin dicampur dengan konsentrat jagung dicampur dengan konsentrat yang mengandung L-karnitin tersebut, kemudian semua bahan dicampur hingga homogen. Perlakuan dilakukan dengan suplementasi $L$ karnitin, minyak ikan tuna dan minyak ikan lemuru sesuai dengan kombinasi perlakuan.

\section{Pelaksanaan penelitian}

Tahap adaptasi dilakukan selama tujuh hari. Pemberian pakan pada tahap adaptasi menggunakan pakan puyuh komersial fase layer yang dicampur dengan pakan perlakuan menjadi satu secara bertahap. Perbandingan pakan puyuh pada hari pertama penelitian yaitu pakan komersial dan pakan perlakuan 80:20, hari kedua dengan perbandingan 70:30, hari ketiga dengan perbandingan pakan 60:40, hari keempat dengan perbandingan 50:50, hari kelima menjadi 40:60, hari keenam menjadi 30:70, hari ketujuh menjadi 20:80, hingga tahap perlakuan dimulai yaitu hari kedelapan persentase pakan perlakuan menjadi $100 \%$. Tahap perlakuan dimulai saat puyuh berumur 77 hari. Pemberian air minum secara 
Tabel 1. Susunan pakan yang digunakan dalam penelitian (\%) (ration composition used in the study (\%))

\begin{tabular}{lccccc}
\hline \hline \multicolumn{1}{c}{ Bahan pakan (feed stuff) } & $\mathrm{P}$ & $\mathrm{P} 1$ & $\mathrm{P} 2$ & $\mathrm{P} 3$ & $\mathrm{P} 4$ \\
\hline Bekatul (ricebran) & 40 & 40 & 40 & 40 & 40 \\
Jagung kuning (yellow corn) & 32 & 0 & 0 & 0 & 0 \\
Jagung kuning terfermentasi (fermented & 0 & 32 & 32 & 32 & 32 \\
yellow corn) & 28 & 28 & 28 & 28 & 28 \\
Konsentrat (concentrate) & 0 & 0 & 0,001 & 0,001 & 0,001 \\
L-karnitin (L-carnitine) & 0 & 0 & 0 & 4 & 0 \\
Minyak ikan tuna (tuna fish oil) & 0 & 0 & 0 & 0 & 4 \\
Minyak ikan lemuru (lemuru fish oil) & 100 & 100 & 100,001 & 104,001 & 104,001 \\
\hline \multicolumn{1}{c}{ Jumlah (sum) } & & & &
\end{tabular}

P0: pakan basal (basal diet).

$\mathrm{P} 1: \mathrm{P}_{0}+100$ persen jagung kuning fermentasi untuk substitusi jagung kuning dalam pakan basal $\left(P_{0}+100\right.$ percent basal ration of fermented yellow corn to substitute yellow corn in basal diet).

P2: pakan $\mathrm{P}_{1}+L$-karnitin 10 ppm $\left(P_{1}\right.$ diet +10 ppm of L-carnitine $)$.

P3: pakan $\mathrm{P}_{2}+$ minyak ikan tuna 4 persen $\left(P_{3}=P_{2}\right.$ diet +4 percent of tuna fish oil).

P4: pakan $\mathrm{P}_{2}+$ minyak ikan lemuru 4 persen $\left(P_{2}\right.$ diet +4 percent of lemuru fish oil $)$.

ad libitum dan frekuensi pemberian pakan sebanyak satu kali per hari pada pukul 08.00. Penimbangan sisa pakan dilakukan 3 tiga hari sekali pada pukul 07.30. Jumlah telur yang dihasilkan kemudian dihitung, dicatat dan ditimbang setiap hari pada pukul 07.00. Jumlah puyuh tiap unit kandang dihitung dan dicatat setiap hari.

\section{Pengukuran kecernaan}

Pengukuran kecernaan in vivo dilakukan pada minggu terakhir penelitian dengan metode total koleksi. Burung puyuh dipilih secara acak sebanyak 2 ekor per kandang per replikasi kemudian ditempatkan dalam kandang individu, sehingga secara keseluruhan digunakan 40 ekor burung puyuh untuk pengukuran kecernaan. Hari pertama dipuasakan selama 12 jam. Air minum diberikan secara ad libitum. Hari kedua sampai dengan hari keempat burung puyuh diberi pakan perlakuan. Burung puyuh dipuasakan kembali selama 12 jam pada hari kelima. Ekskreta ditampung menggunakan nampan yang dilapisi plastik pada hari kedua sampai hari keempat. Selama periode total koleksi, ekskreta disemprot dengan $\mathrm{HCl} 0,2 \mathrm{~N}$ secara berkala setiap 3 jam. Sisa pakan dan ekskreta ditimbang untuk mengetahui jumlah konsumsi pakan dan ekskreta. Ekskreta basah ditimbang untuk mengetahui berat segar kemudian dikeringkan dengan cara diangin-anginkan. Setelah kering ekskreta dibersihkan dari bulu dan kotoran lain kemudian ditimbang untuk mengetahui berat kering udara. Ekskreta dihaluskan kemudian diambil sampel secara komposit untuk kemudian dilakukan analisis proksimat. Sampel pakan dan ekskreta dianalisis kandungan bahan keringnya

Tabel 2. Kandungan nutrien dalam $100 \%$ pakan (nutrient content in $100 \%$ ration)

\begin{tabular}{lrrrrr}
\hline \hline Kandungan nutrien (nutrient content) & \multicolumn{1}{c}{ P0 } & \multicolumn{1}{c}{ P1 } & \multicolumn{1}{c}{ P2 } & \multicolumn{1}{c}{ P3 } & \multicolumn{1}{c}{ P4 } \\
\hline EM (kkal/kg) & $2.749,52$ & $2.797,52$ & 2797,46 & $3.007,60$ & $3.008,36$ \\
Protein kasar (\%) (crude protein (\%)) & 17,14 & 17,78 & 17,78 & 17,09 & 17,09 \\
Lemak kasar (\%) (crude fat (\%)) & 6,96 & 6,96 & 6,96 & 6,92 & 6,92 \\
Serat kasar (\%) (crude fibre (\%)) & 5,02 & 4,38 & 4,38 & 4,23 & 4.23 \\
Ca (\%) & 3,39 & 3,40 & 3,34 & 3,26 & 3,26 \\
P tersedia (\%) (P available (\%)) & 0,53 & 0,53 & 0,52 & 0,51 & 0,51 \\
Air (\%) (water (\%)) & 10,08 & 10,08 & 10,08 & 9,69 & 9,69 \\
Abu (\%) (ash (\%)) & 13,42 & 13,42 & 13,42 & 12,91 & 12,91 \\
\hline
\end{tabular}

Sumber: Hasil perhitungan berdasarkan kandungan nutrien bahan pakan yang digunakan (source : the data above are based on the nutrient content used in this study).

P0: pakan basal (basal diet).

$\mathrm{P} 1$ : $\mathrm{P}_{0}+100$ persen jagung kuning fermentasi untuk substitusi jagung kuning dalam pakan basal $\left(P_{0}+100\right.$ percent basal ration of fermented yellow corn to substitute yellow corn in basal diet).

$\mathrm{P} 2$ : pakan $\mathrm{P}_{1}+L$-karnitin $10 \mathrm{ppm}\left(P_{1}\right.$ diet $+10 \mathrm{ppm}$ of $L$-carnitine $)$.

P3: pakan $\mathrm{P}_{2}+$ minyak ikan tuna 4 persen $\left(P_{3}=P_{2}\right.$ diet +4 percent of tuna fish oil $)$.

$\mathrm{P} 4$ : pakan $\mathrm{P}_{2}+$ minyak ikan lemuru 4 persen $\left(P_{2}\right.$ diet +4 percent of lemuru fish oil). 
dengan cara dipanaskan dalam oven pada suhu $105-110^{\circ} \mathrm{C}$ dan lemak kasarnya menggunakan metode Soxhlet (AOAC, 2005).

\section{Analisis statistik}

Data dianalisis dengan menggunakan analisis ragam atau Analysis of Variance (ANOVA). Apabila dalam hasil analisis ragam didapatkan pengaruh yang berbeda nyata pada perlakuan, maka dilanjutkan dengan uji lanjut Duncan Multiple Range Test untuk mengetahui perbedaan antar perlakuan (Hanafiah, 2005).

\section{Hasil dan Pembahasan}

\section{Konsumsi pakan}

Konsumsi pakan meningkat karena substitusi jagung kuning dengan jagung kuning fermentasi (Tabel 3). Hal ini dikarenakan pakan yang mengandung jagung kuning fermentasi memiliki warna kuning yang lebih cerah sehingga keinginan puyuh untuk mematuk pakan lebih tinggi, diperkuat oleh pendapat Ren et al. (2012) yang menyatakan bahwa unggas lebih senang mengonsumi pakan yang berwarna kuning. Nilai kecernaan bahan kering dan bahan organik pakan yang mengandung jagung kuning fermentasi dalam penelitian ini berturut-turut yaitu $65,75 \%$ dan $66,19 \%$ $(P<0,0001)$. Jagung kuning fermentasi lebih cepat dicerna dan lebih mudah diserap dalam saluran pencernaan. Hasil fermentasi dengan ragi tape adalah senyawa atau bahan organik terlarut yang mudah diserap vili-vili usus halus seperti asam amino esensial dan disakarida (Mao et al., 2013), sehingga dapat meningkatkan kecernaan bahan kering dan kecernaan bahan organik. Semakin mudah pakan diserap, maka laju makanan di dalam saluran pencernaan semakin cepat sehingga tembolok lebih cepat kosong dan mengirimkan sinyal lapar ke hipotalamus (pusat pengatur lapar dan kenyang), karena distansi tembolok belum mencapai suatu kondisi yang menyebabkan timbulnya rasa kenyang maka kegiatan mengonsumsi pakan akan terus ada. Pada akhirnya puyuh akan kembali makan sehingga konsumsi pakan meningkat (Cardoso et al., 2011).

Proses fermentasi dengan ragi tape dapat menyebabkan perubahan terhadap komposisi kimia bahan seperti kandungan asam amino, lemak, karbohidrat, vitamin dan mineral akibat aktivitas dan perkembangbiakan mikroorganisme selama proses fermentasi (Guedes et al., 2008). Aktivitas mikroba ragi tape terjadi melalui beberapa mekanisme produksi enzim hidrolitik seperti amilase, proteinase, pektinase, lipase yang menyederhanakan polimer menjadi monomer yang lebih mudah diserap di dalam saluran pencernaan (Pederson, 1971).

Suplementasi L-karnitin dalam pakan yang mengandung jagung kuning fermentasi menunjukkan tingkat konsumsi yang tidak berbeda. Hal ini disebabkan karena fungsi utama $L$-karnitin yang tidak mempengaruhi konsumsi pakan, melainkan L-karnitin berfungsi membantu metabolisme yang diperlukan untuk mengoksidasi asam lemak rantai panjang dalam mitokondria (Flanagan et al., 2010; Zhang et al., 2014) sehingga tidak berpengaruh langsung terhadap konsumsi. Tingkat konsumsi pakan semakin menurun dengan suplementasi minyak ikan. Hal ini disebabkan karena minyak ikan mengandung energi yang cukup tinggi, sehingga kebutuhan energi puyuh lebih cepat terpenuhi. Daulay et al. (2007) menyatakan bahwa puyuh akan cenderung mengurangi konsumsi bila energi dalam tubuh telah tercukupi dari pakan yang dikonsumsinya.

Suplementasi minyak ikan tuna dan ikan lemuru sebagai sumber PUFA dan energi dalam pakan menunjukkan tingkat konsumsi yang sama. Hal ini dikarenakan kandungan yang hampir sama antara minyak ikan tuna dan ikan lemuru. Ikan tuna dan ikan lemuru bila dipres akan menghasilkan minyak ikan yang kandungan utamanya yaitu EM tidak berbeda jauh, minyak ikan tuna mengandung EM sebesar $8260 \mathrm{kkal} / \mathrm{kg}$ dan minyak ikan lemuru sebesar $8280 \mathrm{kkal} / \mathrm{kg}$ (Sudibya et al., 2007). Maka dari itu, dengan kandungan energi yang hampir sama maka tingkat konsumsi juga hampir sama.

\section{Kecernaan bahan kering (KcBK)}

Hasil analisis variansi menunjukkan rerata $\mathrm{KcBK} \mathrm{P}_{1}$ lebih tinggi daripada $\mathrm{P}_{0}$. Hal ini diduga dikarenakan adanya kandungan jagung kuning fermentasi dalam pakan memiliki daya cerna tinggi sehingga secara keseluruhan pakan memiliki kecernaan yang lebih baik. Aktivitas mikroba ragi tape saat fermentasi terjadi melalui beberapa mekanisme produksi enzim hidrolitik seperti 
amilase, proteinase, lipase yang menyederhanakan polimer menjadi monomer lebih mudah diserap di dalam saluran pencernaan (Budiansyah, 2010), dan pada akhirnya dapat meningkatkan nilai kecernaan. Rerata KcBK $\mathrm{P}_{0}$ berbeda sangat nyata dengan $P_{2}$, hal ini diduga adanya penurunan SK pada pakan $\mathrm{P}_{2}$. Kearl (1982) cit. Yulaelawati (2011) menyatakan bahwa nilai KcBK bergantung pada konsumsi, kandungan EM dan kandungan SK dalam pakan. SK yang tinggi diketahui dapat mengurangi ketersediaan energi dan zat nutrien lain serta memengaruhi kecepatan aliran pakan dalam saluran pencernaan (Mohiti-Asli et al., 2012). Semakin tinggi kandungan SK akan mempercepat laju digesta, semakin cepat laju digesta maka semakin singkat proses pencernaan dalam saluran pencernaan. Laju pakan terlalu singkat mengakibatkan kurangnya waktu yang tersedia bagi enzim pencernaan untuk mendegradasi nutrien secara menyeluruh, sehingga menyebabkan kecernaan menurun (Tillman et al., 1991) sehingga dengan adanya penurunan SK dapat meningkatkan KcBK burung puyuh. Rerata $\mathrm{KcBK} \mathrm{P}_{0}$ berbeda sangat nyata dengan $\mathrm{P}_{3}$ dan $\mathrm{P}_{4}$. Hal ini diduga karena adanya sinergisme fungsi antara jagung kuning fermentasi, L-karnitin dan minyak ikan. Ragi yang digunakan saat proses fermentasi bersifat katabolik atau memecah komponen yang kompleks menjadi zat yang lebih sederhana sehingga lebih mudah dicerna di dalam saluran pencernaan. Selanjutnya, minyak ikan yang mengandung PUFA kaya akan asam arakhidonat yang berfungsi sebagai prekursor pembentukan prostaglandin. Prostaglandin berperan merangsang motilitas usus halus dan berperan dalam proses penyerapan pakan (Turner dan Bagnara, 1976). L-karnitin sebagai senyawa pembawa asam lemak rantai panjang berfungsi menembus membran mitokondria pada $\beta$-oksidasi asam lemak untuk menghasilkan energi (ATP). Ketersediaan energi yang bertambah dapat membantu kerja saluran pencernaan dalam mencerna pakan yang pada akhirnya dapat meningkatkan kecernaan burung puyuh.

Rerata KcBK pakan $\mathrm{P}_{1}$ tidak berbeda dengan KcBK pakan $\mathrm{P}_{2}$. Hal ini dikarenakan bahan pakan sama-sama menggunakan jagung kuning fermentasi sehingga KBK antara kedua perlakuan hampir sama yang menyebabkan KcBK pakan $\mathrm{P}_{1}$ tidak berbeda dengan nilai KcBK $\mathrm{P}_{2}$. Sementara itu, nilai rerata KcBK pakan $\mathrm{P}_{1}$ lebih rendah dibandingkan $\mathrm{P}_{3}$ dan $\mathrm{P}_{4}$. Hal ini diduga karena pakan $\mathrm{P}_{3}$ dan $\mathrm{P}_{4}$ mengandung PUFA dari minyak ikan. PUFA kaya akan asam arakhidonat yang berfungsi sebagai prekursor pembentukan prostaglandin. Prostaglandin berperan merangsang motilitas usus halus dan berperan dalam proses penyerapan pakan (Turner dan Bagnara, 1976),

Tabel 3. Pengaruh perlakuan terhadap kecernaaan dan performa produksi burung puyuh (effect of treatments on digestibility and productive performance of Japanesse quail)

\begin{tabular}{|c|c|c|c|c|c|c|}
\hline \multirow{2}{*}{ Variabel (variable) } & \multicolumn{5}{|c|}{ Perlakuan (treatments) } & \multirow{2}{*}{$\begin{array}{c}\text { Nilai } P(P \\
\text { value })\end{array}$} \\
\hline & $\mathrm{PO}$ & $\mathrm{P} 1$ & $\mathrm{P} 2$ & P3 & P4 & \\
\hline $\begin{array}{l}\text { Konsumsi pakan (g/ekor/hari) (feed } \\
\text { consumption (g/head/day)) }\end{array}$ & $21.03^{b}$ & $23.32^{\mathrm{a}}$ & $23.48^{a}$ & $20.92^{b}$ & $21.00^{\mathrm{b}}$ & $0,0009^{\star *}$ \\
\hline KcBK $(\%)$ & $59,20^{c}$ & $65,75^{b}$ & $68,52^{b}$ & $73,00^{a}$ & $72,08^{a}$ & $<.0001^{\star *}$ \\
\hline $\mathrm{KcBO}(\%)$ & $60,02^{\mathrm{c}}$ & $66,19^{b}$ & $69,15^{b}$ & $73,65^{a}$ & $72,98^{\mathrm{a}}$ & $<.0001^{* *}$ \\
\hline $\operatorname{KcLK}(\%)$ & $66,49^{c}$ & $73,29^{b}$ & $76,82^{b}$ & $84,24^{a}$ & $83,30^{\mathrm{a}}$ & $<.0001^{* *}$ \\
\hline Hen day production $(\%)$ & $54,63^{b}$ & $57,93^{b}$ & $66,84^{a}$ & $72,22^{\mathrm{a}}$ & $72,57^{a}$ & $0,0010^{* *}$ \\
\hline Berat telur (g/butir) (egg weight (g/egg)) & $9.03^{c}$ & $9.58^{\mathrm{b}}$ & $9.61^{b}$ & $10.06^{a}$ & $10.00^{\mathrm{ab}}$ & $0,0005^{* *}$ \\
\hline Konversi pakan (feed conversion) & $4,27^{a}$ & $4,37^{a}$ & $3,66^{\mathrm{ab}}$ & $2,88^{\mathrm{b}}$ & $2,90^{\mathrm{b}}$ & $0,0024^{* *}$ \\
\hline
\end{tabular}

KcBK: kecernaan bahan kering (dry matter digestibility).

$\mathrm{KcBO}$ : kecernaan bahan organik (organic matter digestibility).

KcLK: kecernaan lemak kasar (crude fat digestibility).

P0: pakan basal (basal diet).

$\mathrm{P} 1: \mathrm{P}_{0}+100$ persen jagung kuning fermentasi untuk substitusi jagung kuning dalam pakan basal $\left(P_{0}+100\right.$ percent basal ration of fermented yellow corn to substitute yellow corn in basal diet).

P2: pakan $\mathrm{P}_{1}+L$-karnitin $10 \mathrm{ppm}\left(P_{1}\right.$ diet $+10 \mathrm{ppm}$ of $L$-carnitine)

P3: pakan $\mathrm{P}_{2}+$ minyak ikan tuna 4 persen $\left(P_{3}=P_{2}\right.$ diet +4 percent of tuna fish oil).

P4: pakan $\mathrm{P}_{2}+$ minyak ikan lemuru 4 persen $\left(P_{2}\right.$ diet +4 percent of lemuru fish oil)

** Pengaruh perlakuan sangat nyata $(P<0,01)$ terhadap variabel (treatments effect were highly significant $(P<0.01)$ on variable).

a,b,c Superskrip yang berbeda pada baris yang sama menunjukkan perbedaan sangat nyata $(P<0,01)$ (different superscripts at the same row showed highly significant differences $(P<0.01))$. 
sehingga $\mathrm{KcBK}$ mengalami peningkatan. Rerata KcBK pakan $\mathrm{P}_{2}$ lebih rendah dibandingkan $\mathrm{P}_{3}$ dan $\mathrm{P}_{4}$. Hal ini diduga terjadi karena sinergisme fungsi antara L-karnitin dengan asam lemak yang terkandung pada pakan $\mathrm{P}_{3}$ dan $\mathrm{P}_{4}$. L-karnitin diperlukan sebagai senyawa pembawa asam lemak rantai panjang berfungsi menembus membran mitokondria pada $\beta$-oksidasi asam lemak untuk menghasilkan energi (ATP). Ketersediaan energi yang bertambah dapat membantu kerja saluran pencernaan dalam mencerna pakan yang pada akhirnya dapat meningkatkan kecernaan burung puyuh.

Rerata KcBK pada pakan $\mathrm{P}_{3}$ yang diberi penambahan minyak ikan tuna tidak berbeda dengan rerata KcBK pakan $\mathrm{P}_{4}$ yang diberi penambahan minyak ikan lemuru. Hal ini diduga dikarenakan kandungan BK yang hampir sama antara dua perlakuan mengakibatkan rerata $\mathrm{KcBK}$ yang hampir sama juga.

\section{Kecernaan bahan organik (KcBO)}

Hasil uji lanjut menggunakan uji Duncan's pada KcBO menunjukkan bahwa pakan $P_{1}$ memiliki kecernaan yang secara nyata lebih tinggi dibandingkan $\mathrm{P}_{0}$. Keadaan ini diduga terjadi karena pakan pada perlakuan $\mathrm{P}_{1}$ menggunakan jagung yang telah difermentasi. Fermentasi terjadi melalui dua tahapan yaitu pengubahan karbohidrat komplek (polisakarida) seperti pati yang terdapat dalam bahan baku menjadi bentuk karbohidrat yang lebih sederhana (monosakarida) yaitu gula (glukosa) dan pada proses selanjutnya gula diubah menjadi alkohol oleh khamir dengan hasil sampingan dari reaksi tahap kedua adalah gas $\mathrm{CO}_{2}$ dan asam-asam organik (Pan et al., 2014). Hasil fermentasi dengan ragi tape adalah senyawa atau bahan organik terlarut yang mudah diserap vili-vili usus halus seperti asam amino esensial dan disakarida (Mao et al., 2013) sehingga dapat meningkatkan KcBO. Rerata $\mathrm{KcBO} \mathrm{P}_{0}$ berbeda sangat nyata dengan $\mathrm{P}_{2}$. Hal ini diduga karena adanya peningkatan KcBK pada $\mathrm{P}_{2}$ sehingga KcBO juga ikut meningkat. Rerata KcBO $\mathrm{P}_{0}$ berbeda sangat nyata dengan $\mathrm{P}_{3}$ dan $\mathrm{P}_{4}$. Hal ini diduga karena adanya peningkatan kandungan EM pada pakan yang diberi penambahan minyak ikan tuna dan lemuru. Kandungan energi pakan yang tinggi akan menurunkan konsumsinya. Konsumsi pakan yang lebih sedikit akan memberikan waktu yang cukup bagi saluran pencernaan untuk mencerna pakan sehingga proses penyerapan nutrien lebih optimal.

$\mathrm{KcBO}$ antara pakan perlakuan $\mathrm{P}_{1}$ tidak berbeda dengan KcBO pakan $\mathrm{P}_{2}$. Hal ini diduga dikarenakan bahan pakan samasama menggunakan jagung kuning yang terfermentasi. Perbedaannya pada kandungan $L$-karnitin yang terdapat pada pakan $\mathrm{P}_{2}$ yang mempunyai fungsi utama sebagai transpor asam lemak rantai panjang ke dalam mitokondria di mana proses $\beta$-oksidasi berlangsung (Suwarsito, 2004). KcBO pakan $\mathrm{P}_{3}$ dibandingkan $\mathrm{P}_{4}$ berbeda tidak nyata. Hal ini disebabkan karena kandungan $\mathrm{BO}$ kedua jenis pakan hampir sama.

\section{Kecernaan lemak kasar (KcLK)}

Hasil analisis variansi (Tabel 3) menunjukkan bahwa suplementasi PUFA dan L-karnitin dalam pakan jagung kuning fermentasi meningkatkan KcLK $(P<0,01)$. Rerata nilai KcLK cenderung semakin meningkat dari pakan kontrol seiring dengan penambahan L-karnitin dan minyak ikan. Hasil analisis uji lanjut menggunakan uji Duncan's pada KcLK burung puyuh menunjukkan bahwa KcLK pakan $\mathrm{P}_{0}$ lebih rendah dibandingkan $P_{1}$ dan $P_{2} \quad(P<0,01)$. Peningkatan KcLK ini diduga disebabkan karena KcBO juga meningkat. Lemak kasar merupakan salah satu penyusun BO suatu bahan pakan, sehingga naiknya kecernaan BO akan berbanding lurus dengan kenaikan KcLK (Suprapto et al., 2013). Tillman et al. (1991) menyatakan bahwa setiap bahan dalam pakan memengaruhi daya cerna dari bahan lain jika semua bahan sudah disusun menjadi pakan, hal ini disebut efek gabungan. Adanya efek gabungan pakan karena mengandung jagung kuning fermentasi menyebabkan daya cerna pakan meningkat seiring peningkatan daya cerna jagung kuning fermentasi karena produk fermentasi lebih mudah diabsorpsi usus halus (Mao et al., 2013).

Selanjutnya, KcLK pakan $\mathrm{P}_{3}$ dan $\mathrm{P}_{4}$ juga lebih tinggi bila dibandingkan $\mathrm{P}_{0}$ $(P<0,01)$. Hal ini diduga karena adanya sinergisme fungsi antara jagung kuning fermentasi, L-karnitin dan minyak ikan. Ragi yang digunakan saat proses fermentasi bersifat katabolik atau memecah komponen yang kompleks menjadi zat yang lebih sederhana sehingga lebih mudah dicerna di dalam saluran pencernaan. Enzim yang ber- 
peran dalam mengemulsi lemak adalah lipase, lipase dapat terkandung secara alami pada lemak dan minyak, enzim ini juga dapat dihasilkan oleh mikroorganisme yang terdapat pada bahan pakan yang berlemak (Gaman dan Sherrington, 1992). Sehingga, enzim lipase mudah dihasilkan dan mampu mengemulsi lemak lebih banyak. L-karnitin sebagai senyawa pembawa asam lemak rantai panjang berfungsi menembus membran mitokondria pada $\beta$-oksidasi asam lemak untuk menghasilkan energi (ATP). Ketersediaan energi yang bertambah dapat membantu kerja saluran pencernaan dalam mencerna pakan yang pada akhirnya dapat meningkatkan kecernaan burung puyuh. KcLK pakan $\mathrm{P}_{1}$ tidak berbeda dengan KcLK pakan $\mathrm{P}_{2}$. Hal ini diduga karena kedua pakan mengandung LK yang hampir sama sehingga menyebabkan tidak ada perbedaan KcLK antar kedua perlakuan. Pakan $\mathrm{P}_{1}$ lebih rendah kecernaan lemak kasarnya dibandingkan $\mathrm{P}_{3}$ dan $\mathrm{P}_{4}$. Hal ini diduga karena pakan $\mathrm{P}_{3}$ dan $\mathrm{P}_{4}$ mengandung PUFA dari minyak ikan. PUFA kaya akan asam arakhidonat yang berfungsi sebagai prekursor pembentukan prostaglandin.

Pakan $\mathrm{P}_{2}$ lebih rendah keernaan lemak kasarnya dibandingkan dengan $\mathrm{P}_{3}$ dan $\mathrm{P}_{4}$. Hal ini diduga terjadi sinergisme fungsi antara L-karnitin dan minyak ikan. Penambahan L-karnitin dalam pakan yang mengandung lemak sangat dibutuhkan. Peran penting dari L-karnitin adalah membantu membawa PUFA yang berasal dari minyak ikan melintasi membran mitokondria bagian dalam untuk diubah menjadi energi. Ketersediaan energi yang bertambah dapat membantu kerja saluran pencernaan dalam mencerna pakan yang pada akhirnya dapat meningkatkan KcLK.

Rerata KcLK pakan $\mathrm{P}_{3}$ dibandingkan $\mathrm{P}_{4}$ tidak ada perbedaan tingkat kecernaan lemak kasarnya. Hal ini dikarenakan kandungan lemak yang relatif sama antara minyak ikan lemuru dan tuna yang digunakan dalam pakan yaitu sebesar 5,8 dan $6 \%$, sehingga antara pakan $P_{3}$ dengan $P_{4}$ menunjukkan hasil yang berbeda tidak nyata terhadap KcLK burung puyuh.

\section{Hen day production (HDP)}

Rerata produksi telur meningkat dengan penambahan $L$-karnitin dalam pakan jagung kuning fermentasi (Tabel 3). Fungsi dari $L$-karnitin yaitu sebagai pembawa asam lemak tak jenuh rantai panjang/PUFA ke dalam mitokondria untuk proses metabolisme. Jagung kuning fermentasi merupakan bahan pakan yang mengandung berbagai nutrien termasuk PUFA (Nicholls, 1971) sehingga metabolisme PUFA dalam pakan yang ditambah L-karnitin bisa berlangsung dengan baik. Metabolisme yang baik memberi efek yang baik pula terhadap hidup pokok dan produksi puyuh.

Suwarsito (2004) menambahkan bahwa pemberian L-karnitin mampu meningkatkan aksi Protein Sparring effect dari lemak, sehingga energi dari protein digunakan untuk sintesis protein tubuh, selanjutnya protein bermanfaat untuk pertumbuhan dan produksi. Oleh karena itu terjadi peningkatan produksi telur dengan penambahan L-karnitin 10 ppm dalam pakan jagung kuning fermentasi. Suplementasi Lkarnitin hingga level 25 ppm pada pakan itik tegal dapat meningkatkan kinerja itik petelur (Widiyastuti et al., 2005). Hasil penelitian tersebut dapat dijadikan acuan karena puyuh merupakan jenis unggas yang dengan penambahan 10 ppm L-karnitin pada pakan terbukti mampu menghemat penggunaan protein ditunjukkan dengan produksi telur yang meningkat. Produksi telur puyuh pada perlakuan pakan jagung kuning fermentasi yang mengandung $L$-karnitin tidak menunjukkan perbedaan jika ditambahkan minyak ikan tuna maupun minyak ikan lemuru, dikarenakan proses metabolisme nutrien dari pakan tersebut sama, sebab kandungan nutrien yang sama-sama terdapat asam lemak tak jenuh rantai panjang/PUFA.

\section{Berat telur}

Rerata berat telur semakin meningkat dari pakan kontrol dengan adanya substitusi jagung kuning fermentasi dan suplementasi minyak ikan (Tabel 3). Peningkatan ini disebabkan oleh kandungan asam linoleat yang merupakan asam lemak tak jenuh rantai panjang/PUFA yang banyak terkandung dalam jagung kuning dan minyak ikan, banyaknya kandungan asam lemak tak jenuh bisa dilihat dari bilangan yodium, karena asam lemak tak jenuh mampu mengikat yodium. Bilangan yodium minyak ikan yaitu berkisar 120-195 paling tinggi dibandingkan dengan jenis minyak lainnya (Nicholls, 1971). Sehingga pada pakan ini asam linoleat mampu mengontrol lipida dan protein yang diperlukan untuk perkembangan folikel dan secara langsung mengontrol 
ukuran telur (Suripta dan Astuti, 2006). Walaupun konsumsi menurun dengan penambahan minyak ikan tetapi berat telur tetap terkontrol.

Peningkatan berat telur pada hasil penelitian ini sejalan dengan perbaikan kualitas pakan. Tillman et al. (1991) menambahkan bahwa setiap bahan pakan mempengaruhi daya cerna dari bahan pakan lain jika semua bahan sudah disusun menjadi formulasi pakan, hal ini disebut efek gabungan. Nutrien dalam pakan jagung fermentasi mudah diserap saluran pencernaan sehingga nutrien yang dibutuhkan untuk mempertahankan berat telur bisa digunakan puyuh. Hal ini diperkuat oleh Mao et al. (2013) yang menyatakan bahwa hasil fermentasi dengan ragi tape adalah senyawa atau bahan organik terlarut yang mudah diserap. Kemudian, pakan jagung kuning fermentasi mampu meningkatkan berat telur, dikarenakan konsumsi pada pakan ini juga meningkat. Peningkatan konsumsi dan penyerapan nutrien yang optimal pada akhirnya mampu meningkatkan berat telur. Minyak ikan tuna dan ikan lemuru sebagai sumber PUFA tidak ada perbedaan dalam mengontrol berat telur, karena kandungan minyak ikan tuna dan ikan lemuru yang tidak jauh berbeda.

\section{Konversi pakan}

Nilai konversi pakan lebih rendah pada pakan yang mengandung minyak ikan (Tabel 3). Penurunan nilai konversi pakan disebabkan oleh penurunan konsumsi pakan yang diiringi meningkatnya produktivitas puyuh, ini berarti efisiensi pakan juga meningkat. Tingkat efisiensi pakan tertinggi yaitu dengan penambahan minyak ikan $4 \%$ baik minyak ikan tuna maupun ikan lemuru pada pakan yang menggunakan jagung kuning fermentasi. Konversi pakan puyuh umur 6-11 minggu adalah 3,07 sampai 3,09 sedangkan umur 16 minggu adalah 3,07 sampai 4,09 (Suripta dan Astuti, 2006; Triyanto, 2007). Konversi pakan puyuh pada penelitian ini mampu diperbaiki hingga 2,88 yaitu dengan suplementasi minyak ikan tuna pada pakan jagung kuning tanpa fermentasi. Hasil penelitian Kusuma (2013) menyatakan bahwa nilai konversi pakan menurun dengan suplementasi minyak ikan tuna $4 \%$ dalam pakan yaitu sebesar 3,86 .

\section{Kesimpulan}

Suplementasi $L$-karnitin $10 \mathrm{ppm}$ dalam pakan mampu memperbaiki HDP, jagung kuning fermentasi dapat meningkatkan $\mathrm{KcBK}, \mathrm{KcBO}$, KcLK, dan berat telur. Suplementasi minyak ikan tuna $4 \%$ ke dalam pakan mampu meningkatkan berat telur, sedangkan suplementasi minyak ikan tuna dan minyak ikan lemuru pada pakan jagung kuning mampu memperbaiki nilai konversi pakan puyuh fase produksi.

\section{Daftar Pustaka}

AOAC. 2005. Official Methods of Analysis. $18^{\text {th }}$ edn. Association of Official Agricultural Chemists, Washington, DC.

Bess, F., A. Favero, S. L. Vieira and J. Torrent. 2012. The effects of functional oils on broiler diets of varying energy levels. J. Appl. Poult. Res. 21: 567578.

Budiansyah, A. 2010. Performan ayam broiler yang diberi ransum yang mengandung bungkil kelapa yang difermentasi ragi tape sebagai pengganti sebagian ransum komersial. Jurnal IImiah IImu-IImu Peternakan 5: 260-268.

Cardoso, D., A. Z. M. Salem, F. D. Provenza, R. Rojo, L. M. Camacho and D. G. Satterlee. 2011. Cereal type in diet and housing system influences on growth performance and carcass yield in two Japanese quail genotypes. Anim. Feed Sci. Tech. 163: 52-58.

Daulay, A. H., I. Bahri, dan K. Sahputra, 2007. Pemanfaat buah mengkudu (Morinda citrifolia) dalam pakan terhadap performan burung puyuh (Coturnix-coturnix japonica) umur 0-42 hari. Jurnal Agribisnis Peternakan 3: 33-38.

Flanagan, J. L., P. A. Simmons, J. Vehige, M. D. P. Willcox and Q. Garret. 2010. Role of carnitine in disease. Nutr. Metab. 7: 30-44.

Franz, C., K. H. C Baser and W. Windisch. 2010. Essential oils and aromatic plants in animal feeding - a European perspective. A review. Flavour Fragr. J. 25: 327-340. 
Gaman, P. M. dan K. B. Sherrington. 1992. Pengantar IImu Pangan, Nutrisi dan Mikrobiologi. Diterjemahkan oleh Gardjito, M., S. Naruki, A. Murdiati dan Sardjono. Gadjah Mada Press, Yogyakarta.

Guedes, C. M., D. Goncalves, M. A. M. Rodrigues and A. Dias-da-Silva. 2008. Effects of a Saccharomyces cerevisiae yeast on ruminal fermentation and fibre degradation of maize silages in cows. Anim. Feed Sci. Tech. 145: 2740.

Hanafiah, K. A. 2005. Rancangan Percobaan Teori dan Aplikasi. PT Rajagrafindo Persada, Jakarta.

James, B. W., M. D. Tokach, R. D. Goodband, J. L. Nelssen, S. S. Dritz, K. Q. Owen, J. C. Woodworth and R. C. Sulabo. 2013. Interactive effects of dietary ractopamine- $\mathrm{HCl}$ and $\mathrm{L}$ carnitine on finishing pigs: I. Growth performance. J. Anim. Sci. 91: 32653271.

Kusuma, S. A. 2013. Pengaruh suplementasi minyak ikan tuna dan $L$-karnitin dalam pakan terhadap performan produksi puyuh (Coturnix coturnix japonica). Skripsi Jurusan Peternakan, Fakultas Pertanian, Universitas Sebelas Maret, Surakarta.

Mao, H., H. Mao, J. K. Wang, J. X. Liu and I. Yoon. 2013. Effects of Saccharomyces cerevisiae fermentation product on in vitro fermentation and microbial communities of low-quality forages and mixed diets. J. Anim. Sci. 91: 32913298.

Mohiti-Asli, M., M. Shivazad, M. Zaghari, M. Rezaian, S. Aminzadeh and G. G. Mateos. 2012. Effects of feeding regimen, fiber inclusion, and crude protein content of the diet on performance and egg quality and hatchability of eggs of broiler breeder hens. Poultry Sci. 91: 3097-3106.

Mohseni, M., R. O. A. Ozorio, M. Pourkazemi and S. C. Bai. 2008. Effects of Dietary L-Carnitine Supplements on Growth and Body Composition in Beluga Sturgeon (Huso huso) Juveniles. J. App. Ichthyol. 24: 646-649.
Narinc, D., E. Karaman, T. Aksoy and M. Z. Firat. 2013. Investigation of nonlinear models to describe long-term egg production in Japanese quail. Poultry Sci. 92: 1676-1682.

Nicholls, L. 1971. IImu Gizi dan Ilmu Pangan di Daerah Tropik. PN Balai Pustaka, Jakarta.

Pan, D. D., Z. Wu, T. Peng, X. Q. Zeng and H. Li. 2014. Volatile organic compounds profile during milk fermentation by Lactobacillus pentosus and correlations between volatiles flavor and carbohydrate metabolism. J. Dairy Sci. 97: 624-631.

Pederson, C. 1971. Microbiology and Food Fermentation. The AVI Publishing Co. Inc., Westport, Connecticut.

Prahasta, A. dan H. Masturi. 2009. Agribisnis Burung Puyuh. Pustaka Grafika, Bandung.

Ren, L. Q., H. Z. Tan, F. Zhao, J. T. Zhao, J. Z. Zhang and H. F. Zhang. 2012. Using corn starch as basal diet to determine the true metabolizable energy of protein feedstuffs in Chinese Yellow chickens. Poult. Sci. 91: 13941399.

Shin, D., C. Narciso-Gaytan, J. H. Park, S. B. Smith, M. X. Sanchez-Plata and C. A. Ruiz-Feria. 2011. Dietary combination effects of conjugated linoleic acid and flaxseed or fish oil on the concentration of linoleic and arachidonic acid in poultry meat. Poult. Sci. 90: 1340-1347.

Sudibya, T. Widiyastuti, dan S. S. Santoso. 2007. Transfer omega-3 melalui kapsulisasi dan L-karnitin pengaruhnya terhadap komposisi kimia daging kambing. Laporan Hasil Penelitian Hibah Bersaing IX, Fakultas Peternakan, Universitas Jenderal Soedirman, Purwokerto.

Suprapto, H., F. M. Suhartati, dan T. Widiyastuti. 2013. Kecernaan serat kasar dan lemak kasar complete feed limbah rami dengan sumber protein berbeda pada kambing pernakan etawa lepas sapih. Jurnal IImiah Peternakan 3: 938-946.

Suripta, H. dan P. Astuti. 2006. Pengaruh penggunaan minyak ikan lemuru dan minyak sawit dalam pakan terhadap rasio asam lemak omega-3 dan omega-6 dalam telur burung puyuh. J. Ind. Tropical Anim. Agric. 32: 22-27. 
Suwarsito. 2004. Pengaruh kadar L-karnitin berbeda dalam pakan terhadap kadar lemak daging dan pertumbuhan ikan patin (Pangasius hypopthalmus). Tesis Program Pascasarjana, Institut Pertanian Bogor, Bogor.

Tillman, A. D., H. Hartadi, S. Reksohadiprodjo, S. Prawirokusumo, dan S. Lebdosoekojo. 1991. IImu Makanan Ternak Dasar. Gadjah Mada Press, Yogyakarta.

Triyanto. 2007. Performa produksi burung puyuh (Coturnix coturnix japonica) periode produksi umur 6-13 minggu pada lama pencahayaan yang berbeda. Skripsi Fakutas Peternakan, Institut Pertanian Bogor, Bogor.

Turner, C. D. dan J. T. Bagnara. 1976. Endokrinology Umum. Airlangga University Press, Bandung.

Widiyastuti, T., C. H. Prayitno, dan Sudibya, 2005. Pemanfaatan kepala udang dan suplementasi L-Carnitine pada pakan itik lokal yang mengandung daun lamtoro. Anim. Prod. 9: 30-35.
Zerby, H. N., J. L. Bard, S. C. Loerch, P. S. Kuber, A. E. Radunz and F. L. Fluharty. 2011. Effects of diet and Aspergillus oryzae extract or Saccharomyces cervisiae on growth and carcass characteristics of lambs and steers fed to meet requirments of natural markets. J. Anim. Sci. 89: 2257-2264.

Zhang, J. J., Z. B. Wu, Y. J. Cai, B. Ke, Y. J. Huang, C. P. Qiu, Y. B. Yang, L. Y. Shi and J. Qi. 2014. L-carnitine ameliorated fasting-induced fatigue, hunger, and metabolic abnormalities in patients with metabolic syndrome: a randomized controlled study. Nutr. J. 13: 110-121.

Yulaelawati, A. 2011. Pengaruh suplementasi minyak ikan terproteksi dan LCarnitine dalam ransum terhadap kecernaan bahan kering, kecernaan bahan organik dan kecernaan serat kasar domba lokal jantan. Skripsi Fakultas Pertanian, Universitas Sebelas Maret, Surakarta. 